\title{
'Free In, Free Out': Exploring Dutch Firewall Protections for Irregular Migrant Victims of Crime
}

\author{
Ruben I. Timmerman \\ PhD Candidate, Erasmus Graduate School of Law, Erasmus University \\ Rotterdam, Rotterdam, The Netherlands \\ timmerman@law.eur.nl
}

\begin{abstract}
Arjen Leerkes
Full Professor of Migration, Securitization and Social Cohesion, UNU-MERIT/Maastricht University, Maastricht, The Netherlands Associate Professor of Sociology, Department of Public Administration and Sociology, Erasmus University Rotterdam, Rotterdam, The Netherlands leerkes@essb.eur.nl
\end{abstract}

\author{
Richard Staring \\ Full Professor, Department of Criminology, Erasmus School of Law (ESL), \\ Erasmus University Rotterdam, Rotterdam, The Netherlands \\ staring@law.eur.nl
}

\author{
Nicola Delvino \\ Senior Researcher, Centre on Migration, Policy and Society (COMPAS), \\ University of Oxford, Oxford, UK \\ nicola.delvino@compas.ox.ac.uk
}

\begin{abstract}
Real and perceived risks of deportation may compromise the effective right of irregular migrants to report to the police if they have been a victim of crime. Some localities have therefore introduced so-called 'firewall protection', providing a clear separation between the provision of public services and immigration enforcement. This article explores one such policy in the Netherlands: 'free in, free out'. While the policy began as a local pilot project, in 2015 it was introduced at the national-level alongside implementation of EU Victim's Rights Directive, and currently represents the only national-level example of 'firewall protection' for victims of crime in Europe. This article is based on
\end{abstract}


a socio-legal study that included interviews with informants from governmental and non-governmental organisations. It documents the legal and social reasons for instituting the policy, while critically assessing the challenges in implementation. Finally, it discusses the lessons and opportunities for expanding firewall protection more broadly in a European context.

\section{Keywords}

irregular migration - victims' rights - Victims' Rights Directive - firewall protection sanctuary cities - safe reporting - access to justice

\section{Introduction}

In recent years, increasing efforts have been made in Europe to ensure that irregular migrants ${ }^{1}$ are guaranteed equal access to justice and basic rights should they fall victim to crime. ${ }^{2}$ Perhaps most notably, the EU Victims' Directive, which entered into force in 2015 , sets out to ensure that the rights of all victims of crime are protected, without discriminating on the basis of nationality or residence status. ${ }^{3}$ Among other things, the Victims' Directive signifies - at least on paper-the inclusion of irregular migrants within the wider purview of victims' rights. One of the key aims of the Directive is to ensure that victims are able to safely report to the police. In order to facilitate greater reporting of crime, break the cycle of repeat victimisation, increase victims' confidence in the justice systems of Member States, and reduce the number of underreported crimes, the Directive states that "it is essential that ... competent authorities

1 In the EU context, an irregular migrant is defined as a third-country national who does not fulfill the conditions of entry as set out in the Regulation (EU) 2016/399 (Schengen Borders Code) or other conditions for entry, stay or residence in that EU Member State; European Commission, Migration and Home Affairs (2011), EMN Glossary: Irregular migrant, Brussels: European Commission, available at https:/ec.europa.eu/home-affairs/what-we-do/networks/ european_migration_network/glossary_search/irregular-migrant_en.

2 European Agency for Fundamental Rights (FRA)(2014), Victims of crime in the EU: The extent and nature of support for victims, Vienna: FRA; Platform for International Cooperation on Undocumented Migrants (PICUM)(2015), Guide to the EU Victims'Directive:Advancing Access to Protection, Services and Justice for Undocumented Migrants, Brussels: PICUM.

3 Directive 2012/29/EU of the European Parliament and of the Council of 25 October 2012 establishing minimum standards on the rights, support and protection of victims of crime, and replacing Council Framework Decision 2001/220/JHA, Article 1. 
are prepared to respond to victims' reports in a respectful, sensitive, professional and non-discriminatory manner". ${ }^{4}$

However, when it comes to irregular migrants who are victims of crime, there remain significant challenges and barriers. In particular, human rights observers, scholars, and practitioners in the field of migration have long observed that irregular migrants are often hesitant or unwilling to contact or interact with law enforcement authorities to report crime out of fear of arrest or deportation. ${ }^{5}$ As a result, they are often unable to exercise their basic rights to necessary services, protection, and justice, and are often more vulnerable to perpetrators who are able to exploit their reluctance to report crime. In addition, material limitations on irregular migrants' access to justice are also problematic from a more pragmatic public safety perspective: the lack of opportunity for irregular migrants to safely report crime may result in a lack of crucial intelligence about criminal activity for law enforcement, and may significantly reduce authorities' insight into crime and public safety issues. Such risks are especially prevalent in (urban) contexts with large immigrant communities that include a significant number of irregular migrants. ${ }^{6}$

In view of such human rights and public safety challenges, innovative and diverse initiatives have been developed to promote so-called 'safe reporting' of crime among irregular migrants and ensure greater access to justice for victims. ${ }^{7}$ In particular, some localities have developed what are commonly referred to as 'firewall protection'. 8 These policies set out to prevent local police and service providers from sharing information regarding the immigration status of irregular migrants with immigration authorities when providing essential services. ${ }^{9}$ The purpose is therefore to allow individuals who are a victim or witness of crime to pursue their basic rights without being exposed to arrest

4 Victims' Directive, preamble para. 63.

5 See, inter alia, Kittrie, O.F. (2006), Federalism, deportation, and crime victims afraid to call the police, Iowa Law Review 91(5), pp. 1449-1508; FRA 2014; PICUM 2015.

6 Irregular migrants also often tend to reside in disadvantaged urban neighborhoods with elevated crime risk, making the need to be able to safely report to the police if they are victim of crime all the more pertinent in these areas; see Leerkes, A. (2009), Illegal Residence and Public Safety in the Netherlands, Amsterdam: Amsterdam University Press.

7 Delvino, N. (2017), European Cities and Migrants with Irregular Status: Municipal Initiatives for the Inclusion of Irregular Migrants in the Provision of Services. Oxford: Com PAs, available at https://www.compas.ox.ac.uk/2017/european-cities-and-migrants-with-irregular-status/.

8 Crépeau, F. \& Hastie, B. (2015), The case for 'firewall' protections for irregular migrants: Safeguarding fundamental rights, European Journal of Migration and Law 17(1), pp. 157-183; at p. 166.

9 Ibid., p. 166. 
and immigration enforcement. ${ }^{10}$ Such policies typically contain one or more of the following three components:

1) 'don't ask' - preventing municipal employees from inquiring about the person's immigration status;

2) 'don't tell'-preventing municipal employees from sharing information about a person's immigration status with immigration authorities; and

3) 'don't enforce' - preventing municipal employees from arresting or detaining someone on account of their immigration status. ${ }^{11}$

The most prominent examples of such 'firewall' protections in relation to 'safe reporting' are American 'Sanctuary City' policies, in which some cities in the United States have adopted local ordinances limiting or prohibiting municipal employees-including local police-from cooperating with the US Immigration and Customs Enforcement (ICE). ${ }^{12}$ While these kinds of firewall protections indeed have a long-standing reputation within US public and political discourse, ${ }^{13}$ until recently they have received comparatively little currency within both scholarly academic and policy circles in Europe. ${ }^{14}$ Many EU Member States have provided some possibilities for temporary residence and access to basic services to victims of human trafficking as part of the EUs antitrafficking framework..$^{15}$ In the Netherlands, such protection is found under

10 Carens, J.H. (2008), The rights of irregular migrants, Ethics \& International Affairs 22(2), pp. 163-186.

11 Carlberg, C. (2009), Cooperative Noncooperation: A proposal for an effective uniform noncooperation immigration policy for local governments, George Washginton Law Review 77(3), pp. 740-765; Crépeau, F. \& Hastie, B. (2015), p. 178; Kittrie, O.F. (2006), Federalism, Deportation, and Crime Victims Afraid to Call the Police, Iowa Law Review 91, pp. 1149-1508; Delvino, N. (2019), Safe Reporting of Crime for Victims and Witnesses with Irregular Migration Status in the United States, Oxford: Centre for Migration, Policy and Society (COMPAS).

12 Villazor, R.C. (2010), 'Sanctuary Cities' and local citizenship, Fordham Urban Law Journal 37(2), pp. 574-597; De Graauw, E. (2014), Municipal ID cards for undocumented immigrants: Local bureaucratic membership in a Federal system, Politics \& Society 42(3), pp. 309-330; Delvino 2019, supra note 11.

13 See, inter alia, Villazor 2010; Carlberg 2009; De Graauw 2014.

14 While promising initiatives have been identified at the local level that provide varying degrees of 'firewall' protection that applies to practitioners in the fields of healthcare and education, these rarely extend to police and law enforcement actors; see Crépeau \& Hastie 2015, supra note 8.

15 The European anti-trafficking policy framework is made up a various legal and policy instruments providing access to residence and support for victims, including Council Directive 2004/81 of 29 April 2004 on the residence permit issued to third-country nationals who are victims of trafficking in human beings or who have been the subject of an action to facilitate illegal immigration, and who cooperate with the competent authorities [2004] OJ L261/19; for more information, see Middelburg, A. \& Rijken, C. (2011), The EU 
the Dutch B8/9 (anti-trafficking) regulations, which provides a 'reflection period' and temporary residence to irregular migrants who are victims of certain crimes ${ }^{16}$ However, such protection applies only to a narrow subset of victims, and does not cover the overwhelming majority of crimes. Furthermore, they do not reflect a separation between police and immigration authorities. As such, genuine 'firewall' protections available to all irregular migrants who are victims of crime are few and far between. In 2015, in this very journal, Crépeau and Hastie persuasively argued for need for such 'firewall' protections, in line with safeguarding the fundamental rights of irregular migrants. In the years following, relatively little scholarly work had gone on to further explore existing practices in Europe, particularly when it comes to victims of crime. ${ }^{17}$ In 2019, however, with the aim of addressing this gap, a number of studies were conducted across different European jurisdictions as part of a research and knowledge-exchange project led by the University of Oxford's Centre on Migration, Policy and Society (COMPAS), and specifically exploring law, policy and practices surrounding safe crime reporting by irregular migrants, as well as assessing the legal and political replicability of experiences from the US within European contexts. ${ }^{18}$ This article is based on the findings of the study conducted in the Netherlands, and thus seeks to contribute to this emerging body of research in the area of victim protection for irregular migrants in Europe.

The European context presents unique challenges to implementing firewall protection. First, under the EU Returns Directive, Member States are obligated to issue a 'return decision' to every non-EU citizen not legally authorised to be on their territory, and to enforce that decision by removing the person in question. ${ }^{19}$ Arguably, this return obligation prevents Member States from limiting their domestic authorities from issuing return decisions to (detected)

Legal Framework on Combating Trafficking Human Beings for Labour Exploitation, in: Rijken, C. (ed.), Combating Trafficking in Human Beings for Labour Exploitation. Nijmegen: Wolf Legal Publishers.

16 For more information regarding victim protection under Dutch anti-trafficking legislation, see Timmerman, R., Leerkes, A. \& Staring, R. (2019), Safe Reporting of Crime for Victims and Witnesses with Irregular Migration Status in the Netherlands, Oxford: Centre for Migration, Policy and Society (COMPAS).

17 Crépeau \& Hastie 2015, supra note 8.

18 See "Safe reporting" of crime for victims and witnesses with irregular migration status in the USA and Europe, Oxford: Centre for Migration, Policy and Society (СOMPAS), available at https://www.compas.ox.ac.uk/project/safe-reporting-of-crime-for-victims-and-witnesses -with-irregular-migration-status-in-the-usa-and-europe/.

19 Directive 2008/115/EC of the European Parliament and of the Council of 16 December 2008 on common standards and procedures in Member States for returning illegally staying thirdcountry nationals, oJ L 348, 24.12.2008. 
irregular migrants. While the Returns Directive provides some exceptions for victims of human trafficking, in line with the EU anti-trafficking framework earlier mentioned, ${ }^{20}$ it is uncertain whether or not the Directive allows for a generic non-enforcement of a return decision in situations where an irregular migrant is a victim of crime. Indeed, legal questions surrounding the intersection between the return obligations of Member States under the Returns Directive, and the obligation to provide victims with meaningful safe access to report to the police under the Victims Directive, have so far been largely unexplored.

Nevertheless, Dutch authorities have already begun to open the door for such firewall protection, making it possible for migrants with irregular status to safely report crime through the so-called 'free in, free out' policy. This policy allows such migrants to enter into a police station to report a crime and be guaranteed to be able to leave freely, without being arrested or detained, regardless of the type of crime reported. As suggested by parallel studies conducted in other European jurisdictions, ${ }^{21}$ the Dutch policy appears unique among European countries in that it reflects-at least on paper-a clear separation between victim protection and immigration enforcement. In this respect, it represents one of the only forms of 'firewall protection' available to victims of crime, and has been recognized as a European best practice in the area of victim protection. ${ }^{22}$ Prior to this study, however, there has been strikingly little empirical research examining the 'free in, free out' policy. ${ }^{23}$

20 For instance, under Article 6(4) and Article 11(3) of the Returns Directive; supra note 19.

21 González Beilfuss, M. (2019), Safe reporting of crime for migrants with irregular status in Spain, Oxford: Centre for Migration, Policy and Society (COMPAS); Taverriti S.B. (2019), Safe reporting of crime for victims and witnesses with irregular migration status in Italy, Oxford: Centre for Migration, Policy and Society (сомpas); Van Den Durpel, A. (2019), Safe reporting of crime for migrants with irregular status in Belgium, Oxford: Centre for Migration, Policy and Society (compas).

22 United Nations Human Rights Council (2017), Report on the compendium of principles, good practices and policies on safe, orderly and regular migration in line with international human rights law, Geneva: UNHRC, available at https://reliefweb.int/report/world/report -compendium-principles-good-practices-and-policies-safe-orderly-and-regular, p. 36; PICUM (2012), Strategies to End Double Violence Against Undocumented Women Protecting Rights and Ensuring Justice, Brussels: PICUM, p. 114; PICUM 2015, p. 20.

23 Apart from the report of Timmerman, et al. (2020) on which the current article is based, existing empirical research on the 'free in, free out' policy is limited to a handful of Dutch studies examining the general challenges irregular migrants face in reporting to the police; see Jacobs, M. \& Van Kalmthout, A. (2014), Aangifte te doen:Mogelijkheden om mensen zonder geldige legitimatie op een voor hen veilige manier aangifte te kunnen laten doen van strafbare feiten waarvan zij slachtoffer of getuige zijn geweest, Tilburg: D66; Stichting LOS (2016), Een goede zaak: Onderzoek naar veilige aangifte voor ongedocumenteerden, 
This article seeks to help rekindle the discussion surrounding the need for 'firewall' protection for irregular migrant victims of crime in Europe. More specifically, this article has two central aims: first, it seeks to provide an overview and critical assessment of the kind of 'firewall' protection that currently exists in the Netherlands, while identifying and discussing the various challenges and limitations of these policies. Second, it seeks to identify the unique features of the Dutch system that distinguish it both practically and juridically from other jurisdictions, at the same time offering a reference model for the adoption of potential 'firewall' protections in other European countries. The Netherlands and the 'free in, free out' policy serve as a particularly valuable case-study for exploring the challenges and limitations of firewall protections within a European context. In particular, the Netherlands is characterized by a 'thick' immigration enforcement system and comparably strict interior policing of unauthorised migrants. ${ }^{24}$ This raises a number of important challenges to the development and implementation of firewall protection, including a strong tension between the enforcement of immigration control and deportation on the one hand, and high-level public safety and victim protection demands on the other. We argue that this results in a 'thin' firewall that does provide some limited protection through a 'do not enforce' system, but does not set out a complete separation between regular police and immigration control.

The study was carried out in two phases. First, desk research was conducted in order to gain a better understanding of the background and context of the legal framework and policies surrounding 'safe reporting' for irregular migrants in the Netherlands. It involved an analysis of the relevant regional and domestic legislative and policy instruments, as well as a comprehensive review of the broader secondary literature, both English and Dutch, focusing in particular on existing empirical knowledge on policy outcomes of various 'safe reporting' and 'firewall' practices in Europe and the Netherlands. For the second phase of research, in-depth interviews were conducted with eight key informants from government, law enforcement, and civil society. ${ }^{25}$ These informants were

Rotterdam: Stichting Los; Leermakers, S.D.E., Simons, E.I. \& Noteboom, F. (2018), 'Aangifte doe je niet': Een studie naar factoren die een negatieve invloed hebben op de aangiftebereidheid van Nederlandse, minderjarige slachtoffers van seksuele uitbuiting, Den Haag: Centrum tegen Kinderhandel en Mensenhandel.

24 Leerkes, A. \& Van Houte, M. (2020), Beyond the deportation regime: Differential state interests and capacities in dealing with (non-)deportability in Europe, Citizenship Studies, pp. 1-20, doi: 10.1080/13621025.2020.1718349; Leerkes, A., Varsanyi, M. \& Engbersen, G. (2012), Local limits to migration control: Practices of selective migration policing in a restrictive national context, Police Quarterly 15(4), pp. 446-475.

25 In total, eight in-depth interviews were conducted with informants from the Dutch Ministry of Justice and Security; the National Police; the Immigration Police (AVIM); 
consulted so as to better understand and contextualise the relevant policies and practices identified.

As an exploratory study, the findings presented contain a number of important limitations. First, this article does not provide a comprehensive examination of access to justice for irregular migrants, but rather focuses more narrowly on the practice and implementation of Dutch policies at the initial stage of crime reporting. It does not address the various challenges surrounding victim involvement in trials and court proceedings. Second, no irregular migrants were interviewed. As such, apart from interviews with civil society actors who were able to reflect on the experiences of their undocumented clients, this study lacks the perspective of irregular migrant victims themselves.

Despite these limitations, this study presents one of the few scholarly examinations of the 'free in, free out' policy as an early form of 'firewall' protection for irregular migrants who are victims of crime within a European context. ${ }^{26}$ It provides insight into the challenges and limitations of these protections, and captures the perspectives of a variety of stakeholders with relevant expertise and experience. In this respect, it serves as a valuable contribution for further expanding firewall protections, and research on these protections, across Europe.

The analysis is presented in four sections: (1) an overview of the Dutch immigration control landscape, including the key internal migration control instruments and the organizational structure and competencies of the national police and immigration authorities; (2) an overview of the existing victim protection mechanisms for irregular migrants in the Netherlands, including a discussion of how the 'free in, free out' policy emerged; (3) a detailed examination of how the policy unfolds on the ground during implementation; and (4) a critical assessment of the key challenges and limitations of the policy.

\section{Overview of the Dutch Immigration Enforcement Landscape}

Although the EU has set out a broad legal and regulatory framework to establish greater harmonization on immigration and asylum matters, there nevertheless remains considerable variation in how different European countries respond to irregular migration. This variation carries important implications

the National Rapporteur on Trafficking in Human Beings (NRM); FairWork; the National Support Centre for Undocumented Migrants (Stitching LOS); Stichting STIL; and Stichting Vluchtelingen in de Knel; all interviews were carried out between Feb.-March 2019. 
in terms of the possibility for irregular migrants to safely report crime to the police. In their article on European migration enforcement regimes, Leerkes and Van Houte explore the differences between 12 European countries and how they respond to irregular migration. ${ }^{27}$ The authors develop a typology by which to distinguish between different types of migration control infrastructure in terms of state interests and capacity. In their findings, Leerkes and Van Houte identify that the Dutch migration control system tends towards a 'thick' enforcement regime, combining strong enforcement interests with extensive enforcement capacity. ${ }^{28}$ The following headings will identify more specifically the features of this 'thick' migration control infrastructure that impact both the need for, and limitations of, 'firewall' protections with regards to safe reporting to the police. This section therefore identifies the unique legal features of the Dutch system of immigration control that make it distinct from other jurisdictions, and helps to later identify the source of existing gaps and challenges in practice and implementation. While the Dutch policies of immigration enforcement still differ considerably from those found in various other European countries, 'thicker' enforcement policies are increasingly common internationally, both in Europe and in North-America. ${ }^{29}$ In that sense, the Netherlands constitutes a strategic case of firewall protection in a context where the national state has considerable interest in, and capacities for, postarrival immigration enforcement. The following provides an overview of the features of the Dutch migration control landscape as is relates to (1) the key internal migration control policy instruments, and (2) the organizational structure and competencies of the police and immigration authorities.

First, there are three legal instruments pertaining to irregular migrants in the Netherlands that are especially relevant for the present purposes. First, the Aliens Act [Vreemdelingenwet] 2000 sets out all relevant rules pertaining to unlawful residence, asylum procedures, and administrative detention and deportation. Importantly, under this legislation unauthorised residence in itself is not a criminal offence, but rather a violation of administrative law that could result in administrative detention and deportation. ${ }^{30}$ Under the Aliens

27 Leerkes \& Van Houte 2020, supra note 24.

28 Ibid.

29 De Haas, H., Natter, K. \& Vezzoli, S. (2016) Growing Restrictiveness or Changing Selection? The Nature and Evolution of Migration Policies, International Migration Review, pp. 324367, doi: 10.1111/imre.12288; Leerkes, A., Leach, M. \& Bachmeier, J. (2012), Borders Behind the Border. An Exploration of State-level Differences in Migration Control and their Effects on U.S. Migration Patterns, Journal of Ethnic and Migration Studies 38 (1), pp. 111-129.

30 In some situations irregular residence may result in a criminal misdemeanor sanction; for instance, if the individual is found to have violated an official 'entry ban'. 
Act 200o, all Dutch police are authorised to stop persons in order to check their identity, nationality, and residence status if there exists a 'reasonable suspicion' [redelijk vermoeden] of irregular residence. ${ }^{31}$ Second, the Linking Act [Koppelingswet], which came into force in 1998, plays an important role within the Dutch migration control landscape. It ensures that only immigrants with valid residence permits can access the formal labour and housing markets, social security benefits and public services. To achieve this aim, it allows a wide range of public registration data necessary for gaining access to social security, housing, welfare, and medical care to be cross-checked in order to verify an individual's residence status. ${ }^{32}$ In this respect, it is often seen as a centrepiece of Dutch internal migration control; one that 'recruits' public service professionals to screen for residence status before providing services. ${ }^{33}$ Early iterations of the Linking Act proposed an additional obligation on all public service workers to also report irregular migrants to Dutch immigration enforcement. However, this reporting obligation was eventually removed from the Act, largely as a result of political pushback by service professionals. ${ }^{34}$ Third, the Identification Act [Wet op de Identificatieplicht] requires that all persons age 14 or older in the Netherlands are required to show a valid proof of identification to the police upon request-also known as an identification requirement [identificatieplicht $].^{35}$

In short, these legal instruments reflect three distinct features of the Dutch migration control system that may identified as especially relevant to policy and practice relating to 'firewall' protection; namely: (1) the Netherlands maintains a sweeping digital infrastructure — set out through the Linking Actwhereby information concerning an individual's residence status is easily accessed by an extensive range of national, regional, and local public agencies; (2) every person in the Netherlands is required to provide valid proof of identification to the police upon request; and (3) all police are authorised to stop persons in order to check their identity, nationality, and residence status if there exists a 'reasonable suspicion' of irregular stay. ${ }^{36}$

31 Aliens Act 2000, Article 50(1); Leerkes et al. 2012, supra note 29.

32 Van der Leun, J. (2003), Looking for loopholes: Processes of incorporation of illegal immigrants in the Netherlands, Amsterdam: Amsterdam University Press; Leerkes, A. (2009), Illegal Residence and Public Safety in the Netherlands, Amsterdam: Amsterdam University Press.

33 Van der Leun 2003, p. 115.

34 Ibid., p. 124, 151.

35 Identification Act [Wet op de Identificatieplicht], Article 2; Leerkes et al. 2012, supra note 29 .

$36 \quad$ Aliens Act 2000, Article 5o(1). 
Second, in relation to the role of police and immigration authorities responsible for enforcing immigration control, there are a number of important observations that can be made. In the first place, the Netherlands does not have a single federal immigration authority, such as the US Immigration and Customs Enforcement (ICE) ${ }^{37}$ Rather, the Dutch immigration control system is made up of a number institutional actors intended to cooperate in an integrated way through information-sharing and other activities as partners in an institutional 'chain'-referred to in Dutch as the 'vreemdelingenketen'. ${ }^{38}$ Within this chain, the key institutional actor responsible for supervising and enforcing compliance with Dutch immigration law and preventing unauthorised residence, and the actor most relevant to 'safe reporting' in the Netherlands, is the AVIM [Afdeling Vreemdelingenpolitie, Identificatie en Mensenhandel], or Immigration Police, which is a distinct unit of the Dutch National Police.

The Netherlands has had a National Police service since January 2013, which consists of ten regional units. ${ }^{39}$ The main organisational structure of the Police has three distinct levels—national, regional, and local — that coordinate closely with one another. ${ }^{40}$ The AVIM is the division of the National Police specifically responsible for supervising and enforcing compliance with immigration law and preventing unauthorised residence, and operates at the regional level. The AVIM may apprehend and arrest irregular migrants, carry out identity investigations, and determine whether or not arrested unauthorised migrants should be held in immigration detention. ${ }^{41}$ Every regional unit of the police is further divided into 'districts'. While the AVIM operates regionally, it coordinates with the local districts. ${ }^{42}$ The local level of the police consists of 'Basisteams' that are made up of regular duty officers [wijkagenten] who have ordinary policing

37 Lasch, C.N., Chan, R.L., Eagly, I.V., Haynes, D.F. \& Lai, A. (2018), Understanding 'Sanctuary Cities', Boston College Law Review 59(5), pp. 1705-1773; Delvino 2019, supra note 11.

38 Ministry of the Interior and Kingdom Relations (2013), Basis start architectuur van de vreemdelingenketen: Kennis delen, informatieve gebruiken, samen doen, The Hague: Ministry of the Interior, available at https://www.digitaleoverheid.nl/wp-content/ uploads/sites/8/2017/o1/architectuur-van-de-vreemdelingenketen.pdf.

39 Politie (2015), De lokale positie van de nationale politie: Een eerste verkenning. Apeldoorn: Politieacademie.

40 Ibid.

41 See Amnesty International (2018), Hetrechtop vrijheid:Vreemdelingendetentie, het Ultimum Remedium-begingsel. Amsterdam: Amnesty International, p. 11, available at https:// www.amnesty.nl/content/uploads/2018/o2/AMN_18_o8_Rapport-het-recht-op-vrijheid _DEF_web.pdf?x73404.

42 Dutch National Police (n.d.), Organisatie regionaal en lokaal, available at https://www .politie.nl/over-de-politie/organisatie-regionaal-en-lokaal.html; stakeholder interview, AVIM, Feb. 2019. 
competences. Although regular duty police officers are not primarily responsible for supervising and enforcing Dutch immigration law, they are allowed to stop a person if there exists a 'reasonable suspicion' of irregular status and, if necessary, make an arrest to examine the person's residence status. ${ }^{43}$ When an individual is held or arrested by a regular duty police officer and it is discovered that they are not authorised to reside in the Netherlands, the officer will in most cases make contact with the AVIM and transfer the individual over to their custody ${ }^{44}$ However, regular duty officers maintain a degree of discretionary competence in deciding whether or not to contact immigration police. In short, it is useful to distinguish between: (1) regular duty police, which operate at the local level; and (2) the AVIM or immigration police, which operate at the regional level. However, both of these have the authority to stop and apprehend persons suspected of unlawful stay, while both are also part of the same national police organisation, under the ultimate authority of the Minister of Justice and Security, collaborating closely with one another. This structure and collaboration is important to understanding how the reporting process unfolds in practice.

To summarize, the nature of the Dutch migration enforcement system presents significant barriers to the degree of protection afforded to irregular migrants, particularly in relation to the 'don't ask' and 'don't tell' components of the firewall approach. The system demands that irregular migrants disclose information concerning their identity and residence status to police upon request; provides for the digital infrastructure whereby that information is shared in one form or another between units and agencies—including the immigration police - at various levels of governance; and is structured in a manner that encourages intimate cooperation between local police and immigration authorities. As will be demonstrated in subsequent sections of this article, these features of the Dutch context exposes the 'free in, free out' policy to significant challenges when it comes to ensuring meaningful protection to irregular migrant victims of crime. Implementation

The 'free in, free out' policy first began as part of a local pilot project initiated by the police of Amsterdam, in collaboration with local migrant support

43 Leerkes, Varsanyi \& Engbersen 2012.

44 Interviews with AVIM and Police (Amsterdam), Feb. 2019. 
organisations, and with the support of the Dutch Ministry of Justice and Security ${ }^{45}$ The policy stemmed from both pragmatic as well as rights-based arguments. From stakeholder interviews with government and law enforcement actors, it was clear that the 'free in, free out' policy was borne in large part out of a sense among local police that a significant part of their community was 'invisible' to them. As one of our informants from the police explained:

At that time we realised in Amsterdam that there was a really large group of people that we just didn't have any sight of. For instance, in the area around Bijlmer. ${ }^{46}$ We had no connection with them, we didn't know who they were, they weren't registered, and every now and then, when a crime was committed somewhere, we all of a sudden came in contact with them. [...] So we decided that we wanted to get to know these neighbourhoods and these people better. But when we talked to NGOs, they told us 'yeah, but they are undocumented, and are scared that they will be picked up'. [...] That's how it started. ${ }^{47}$

In the years following the initiation of the pilot project in Amsterdam, the 'free in, free out' policy was extended to additional municipalities, including the cities of Utrecht and Eindhoven. ${ }^{48}$ Finally, the practice was formally recognised as part of the official implementation of the EU Victims' Directive in the Netherlands, and was introduced as national policy in $2015 .{ }^{49}$

Despite its national implementation, however, from a juridical perspective the 'free in, free out' policy remains a decidedly amorphous legal conception. It is not formally codified in national legislation, but is mentioned in an official 'explanatory memorandum' [Memorie van toelichting] released by the Dutch Parliament alongside the official implementation of the EU Victims' Directive. ${ }^{50}$ In practice, however, it is often referred to as a 'gentlemen's

45 Jacobs \& Van Kalmthout 2014, supra note 23; Stichting LOS 2016, supra note 23, at p. 14.

46 Bijlmer refers to the Bijlmermeer, a prominent neighborhood in Amsterdam that is known for its large immigrant population; see also Van der Leun 2003, at p. 62.

47 Interview with Police (Amsterdam), Feb. 2019.

48 Stichting LOS 2016, supra note 23, at p. 12.

49 See Memorie van Toelichting [Explanatory Memorandum] 2014/2015, 34236 nr. 3, Implementatie van richtlijn 2012/29/EU van het Europees parlement en de Raad van 25 oktober 2012 tot vaststelling van minimumnormen voor de rechten, de ondersteuning en de bescherming van slachtoffers van strafbare feiten, en tervervanging van Kaderbesluit 2001/220/ JBZ (PbEU 2012, L 315), available at https://zoek.officielebekendmakingen.nl/kst-34236-3 .html.

5o Ibid. 
agreement.51 The policy has been detailed in an internal police 'work instruction', which guides regular duty officers on 'safe reporting' policies for victims of crime with irregular status. This work instruction states that its primary purpose is to set out a 'national uniform procedure for the recording of a report or witness testimony of a victim without residence status', citing as its source Article 1 of the EU Victims' Directive. ${ }^{52}$ The work instruction specifically identifies the right of irregular migrants to safely report to the police under the Victims Directive, while also citing several additional rights specifically set out under the Victims' Directive to which irregular migrant victims are entitled. ${ }^{53}$ Importantly, the work instruction also emphasizes that - apart from victims of human trafficking - the 'free in, free out' policy does not provide the victim with any rights with respect to their residence status. ${ }^{54}$ The work instruction furthermore details the procedure by which an officer must process a report.

While the instruction explicitly states that the person in question shall not be subject to immigration enforcement, it is decidedly vague with respect to the 'don't ask' and 'don't tell' components of the firewall approach. First, the instruction specifies that the identity and contact information of the irregular migrant in question must be recorded and registered in the Basisvoorziening Handhaving $(\mathrm{BVH})$ - the incident registration database of the National Police-either by an official valid ID or any other provisional identification details. ${ }^{55}$ Although it states that the identity of the irregular migrant "must not be unnecessarily questioned", 56 it does not explicitly forbid officers from inquiring about their residence status. Nor does it explicitly restrict officers from communicating any information with immigration authorities, such as the immigration police. As will be shown, both of these gaps contribute to significant challenges in terms of the degree of protection that is provided to irregular migrant victims.

51 Interviews with AVIM and Police (Amsterdam), Feb. 2019; see also Delvino 2017, supra note 7, p. 13 .

52 Translated; Werkinstructie 'Veilige aangifte slachtoffers zonder verblijfstatus in Nederland'. The work instruction is not officially published by the National Police; however, it is available online on the website of Stichting Los, the National Support Centre for Undocumented Migrants at http://www.stichtinglos.nl/sites/default/files/los/20160307\%20 Werkinstructie\%2oVeilige\%2oaangifte\%2oslachtoffers\%2ozonder\%2overblijfsstatus.pdf. This includes the right to understand and be understood (Art. 3); the right to information (Arts. 4-6); the right to free access to an interpreter (Art. 7); and the right to access victim support services (Art. 8). Also in line with the purpose and aims of the EU Victims' Directive, as specified in paragraph 10 of the Directive's Preamble.

55 Supra note 52.

$5^{6}$ Translated; work instruction, supra note $5^{2}$. 
Interestingly, the largely informal character of the current 'free in, free out' policy is not incidental, but rather a deliberate policy choice made at the time of national implementation for both political and practical reasons. In the first place, policy and decision-makers involved in the nation-wide introduction of this policy adopted a pragmatic approach, treating the issue of 'safe reporting' primarily as a policing and crime prevention-related matter, rather than a migration issue. As one informant from the Ministry of Justice and Security described:

We had the idea that it should remain low-key. So, we asked ourselves, 'is it actually a migration problem, or is it more just something for the police?' It is not something with which the State Secretary wanted to say 'I am doing this'. It was more like, 'okay, if it doesn't bother me, then go ahead. Do what you think is best'. [...]. We thought, let the police deal with it, it should come from the point of crime prevention.

Likewise, both the Ministry of Justice and Security and Public Prosecution Service (OM) explored the possibility of providing a more comprehensive regulation similar to that available for trafficking victims under the $\mathrm{B} 8 / 9$ regulation, which includes specific procedures for (temporary) residence, accommodation, and other support. ${ }^{57}$ Dutch policy-makers eventually decided against this and favoured the 'free in, free out' policy as a more simple regulation prioritising a pragmatic policing and crime prevention agenda. ${ }^{58}$ Importantly, it was identified that the national implementation of the EU Victims' Directive also played an important role in offering the political opportunity to decouple the question of 'safe reporting' from more politicised issues surrounding immigration control and returns: police would simply align their practice with the EU minimum standard to treat irregular migrants in the same manner as all other victims of crime, leaving out questions of migration policy altogether. ${ }^{59}$ The development of the 'free in, free out' policy in this way demonstrates the efforts made by Dutch policy-makers to balance important public safety concerns and victims' rights interests with immigration enforcement and return interests.

As it stands, then, the 'free in, free out' policy exists as a semi-formal arrangement allowing migrants with irregular status freely to enter into a police station to report a crime and be permitted freely to leave without being arrested

$57 \quad$ Supra note 16.

58 Interview with Ministry of Justice and Security, Feb. 2019.

59 Interviews with Police (Amsterdam) and Ministry of Justice and Security, Feb. 2019. 
or held in custody. ${ }^{60}$ Importantly, it offers no additional benefits in terms of obtaining residence status or additional support services. After reporting a crime, irregular migrants remain at risk of being arrested and detained by immigration authorities at any time on grounds of their irregular status.

While the 'free in, free out' policy has been recognised by some human rights observers as a European 'best practice' in the area of victim protection of irregular migrants, ${ }^{61}$ there has been striking little empirical evaluation of the policy: how the policy unfolds in practice, what the outcomes are, and what gaps and challenges exist. ${ }^{62}$ This section will first briefly discuss what is known regarding the actual use of the policy-e.g. how often it is used, by who, and for what kinds of crimes - and then provide a detailed analysis how the reporting process unfolds in practice.

The 'free in, free out' policy is not actively monitored or evaluated, and there has been no systematic empirical examination by scholars. As a result, information depends almost entirely on anecdotal information, and the experiences and estimations of stakeholders, such as the police and civil society actors. Based on those experiences, there are a few observations worth highlighting. First, situations of 'safe reporting' among clients with irregular status involve a strikingly diverse range of criminal activity. Specific examples and cases were identified during interviews with civil society actors, drawing on the experiences of their undocumented clients. The kinds of crimes that were identified included various forms of labour exploitation, from unpaid wages to forced

6o There is considerable debate in the Netherlands regarding the legal status of internal work instructions (cf. Böcker, A. \& Terlouw, A. (Eds) (2013), De gelaagdheid van de vreemdelingenregelgeving in historisch en vergelijkend perspectief, Deventer: Kluwer). While the executive branch of government has occasionally regarded such instructions as informal policy rules, from which no rights can be derived, that view has been challenged. Arguably, the fact that the work instruction has been made publicly accessible online, and that the policy itself has been included in an Explanatory Memorandum of the Dutch Parliament alongside the official implementation of the Victims' Directive (see supra note $5^{\circ}$ ), confers to it a quasi-legal character that could potentially allow an irregular migrant who is administratively detained while reporting a crime to successfully challenge the detention in a legal setting. However, further establishing the precise legal character of the work instruction and the 'free in, free out' policy as it relates to enforceability extends beyond the scope of the present study.

61 UN Human Rights Council 2017; PICUM 2012; PICUM 2015.

62 Supra note 23. 
labour; theft, including mugging; various forms of sexual violence, including rape; forced prostitution; forced drug trafficking; domestic violence; blackmail; and stalking. It was generally identified among both civil society and law enforcement participants that irregular migrants rarely go to the police to report 'minor crimes', such as a stolen bicycle or wallet, the reason being that irregular migrants are often reluctant to run the risk of exposing themselves to police unless there is a clear legal interest.

\subsection{Initial Report, Identification and Referral}

The following sections attempt to break down the irregular migrant's trajectory through the 'reporting' process. In particular, a distinction may be made between two broad stages; namely, (1) identification and referral, and (2) victim support and follow-up procedures.

The first stage of identification and referral refers to the process unfolding after an irregular migrant indicates to the police that he/she wishes to report a crime. Under the policy irregular migrants are in principle able to go to any police office/police officer to safely report any crime. However, law enforcement officers maintain a considerable degree of discretion in determining when and how to apply the policy. Indeed, the extensive discretionary authority of law enforcement actors in the Netherlands has been well-documented. ${ }^{63}$ In relation to the 'free in, free out' policy specifically, there are two instances in this early process of identification and referral where discretion is crucial ; namely, (1) in deciding whether or not the individual is a victim of crime and should be permitted to 'safely' make a report, ${ }^{64}$ and $(2)$ in deciding whether or not to contact the immigration police.

In relation to the first point, there exists a significant 'grey area' in determining under what kinds of situations irregular migrants should be considered 'victims' for the purposes of a 'free in, free out' policy. One informant from the immigration police described the situation as follows:

63 See, inter alia, Brouwer, J., Van der Woude, M. \& Van der Leun, J. (2017), (Cr)immigrant framing in border areas: decision-making processes of Dutch border police officers, Policing \& Society 28(4), pp. 448-463; Van der Woude, M. \& Van der Leun, J. (2017), Crimmigration check in the internal border areas of the EU: Finding the discretion that matters, European Journal of Criminology 14(1), pp. 27-45.

64 It is important to note that this initial stage of determining whether or not an individual is a victim of crime applies to all situations of crime reporting, not just those involving irregular migrants; nevertheless, it is important to highlight as a key stage in which the discretion of the officer plays a particularly salient role in determining if the 'free in, free out' policy should be applied. 
Who decides when someone is a victim? Look, we might have someone that walks into the police station and says 'hey, I want to make a report for my passport'. Well, according to me a 'safe report' is not necessary for that. Let's first go to the immigration office, and then we will see [...]. But there are also times when we come across domestic violence, for instance, and then we say right away, 'we don't have anything to do with that'.

Irregular migrants reporting an incident to the police are therefore not automatically considered 'victims' for the purposes of the 'free in, free out' policy. Again there remains a degree of discretion on the part of the individual officer in determining which situations are appropriate for application of a 'free in, free out' approach. Although it was recognised among both law enforcement and civil society actors that, in general, the policy is primarily utilised in situations involving 'more serious' crimes, this nevertheless creates uncertainty for irregular migrants, particularly since victims may have differing attitudes as to what situations are 'serious' enough to involve the police.

In relation to the second point, the discretionary authority of regular officers also plays an important role in decision-making around whether or not to contact immigration police. A number of points are worth highlighting. First, when a regular officer comes into contact with an irregular migrant, they have mobile access - via individual cellular devices - to a database with information on the individual being stopped or arrested. This information includes details concerning the person's residence status, and is available to both regular duty officers and immigration police. If the database indicates that the individual in question is not authorised to reside in the Netherlands, the officer will contact the immigration police (AVIM). One informant from the immigration police explained this process as follows:

We have a police app, and if I arrest someone I can just check their information, and I know right away where they live, what they have done, and so on. I pull that out of the system. So if it is an illegal alien, a short message comes up that says: "Resides illegally in the Netherlands", so I contact the immigration police. ${ }^{65}$

This dynamic has particularly important implications in relation to the 'don't ask' and 'don't tell' components of firewall protection. With respect to the

65 If no information is available in the system, it is assumed that the person in question is an irregular migrant and does not have legal residence status; interview with AVIM, Feb. 2019. 
former, it means that the officer may learn about the residence status of an individual without even needing to specifically inquire about it, purely as a consequence of sharing access to a database wherein that information is available. With respect to the latter, regular duty officers who come into contact with an irregular migrant are generally expected to report the person to the immigration police. ${ }^{66}$ Given that the 'free in, free out' work instruction does not explicitly prohibit the officer from contacting the immigration police and informing them of the incident or providing them with other information, ${ }^{67}$ it therefore remains common practice for regular duty officers to report irregular migrants to the immigration police, including when the individual has indicated that they wish to exercise their right to safely report a crime. In particular, they might consult with the immigration police if they feel that they require additional advice or information, or if they are uncertain about the relevant immigration law or other legal particularities. It was further identified that the practice of contacting immigration police often stems from a lack of knowledge and awareness among many regular duty officers about the 'free in, free out' policy.

Once contacted, the AVIM will make a determination as to whether or not to take over the case. If the individual is determined to be a victim of crime, the immigration police take no further enforcement action. ${ }^{68}$ However, as the informant from the AVIM explained, the immigration police often still register the information in their system:

Last month, somebody reported that they were a victim of a mugging on the street. The officer involved contacted us because the person was as illegal as can be, but we didn't take over the case. We said right away that we don't do anything with that, because he was a victim and he was going to report. So we didn't take him, but I do know about it now. So I put it in my system that he was a victim, but for the rest I don't do anything with it.

It is clear that the discretion exercised by police officers (whether from the immigration police or regular duty officers) plays an important role in 'safe reporting' outcomes, and may contribute to a lack of uniform application. Additionally, the procedure raises serious questions as to whether or not this can really be said to be a 'firewall' at all between regular duty police and

66 Although they are not obligated to do so; the decision falls to the discretion of the officer; interview with AVIM, Feb. 2019.

67 Supra note 52.

68 Supra note $5^{2}$. 
immigration authorities. Section 5 will discuss these criticisms in more detail; first we move on to the process unfolding immediately after the irregular migrant has safely and successfully reported a crime.

\subsection{Follow-up Procedures and Victim Support}

First, when an irregular migrants reports a crime, either as a witness or victim, there are generally speaking two possible outcomes. ${ }^{69}$ One possibility-which is common to all reports of crime, regardless of whether or not the individual is undocumented-is that the police determine that there is not enough evidence to support taking the case any further. The incident is recorded, but there is no further follow-up investigation or prosecution. The second possibility is that there is enough credible evidence for the police to move on to further investigation. One of the police informants described the process as follows:

If the person comes with really concrete information concerning a crime $[\ldots]$ then the police get to work. If the person is required for the investigation, then contact is taken up with the public prosecutor, and the relevant investigation team will explain to the public prosecutor that 'hey, the witness is not just a witness, but is also an undocumented person'. Then in practice what happens is that some custom arrangements are made $[\ldots]$ to ensure that the person is not picked up and deported during that time. ${ }^{70}$

The 'free in, free out' policy therefore does not set out any formal framework for following-up with irregular migrant victims once they have reported a crime. Instead, informal and ad hoc arrangements are made to ensure that such victims, to the extent that they are valuable for criminal proceedings, are not detained or deported. During the investigation and proceedings, the irregular migrant is expected to be available to authorities if necessary.

While further details regarding follow-up procedures as they relate to victim involvement in trials and court proceedings are beyond the scope of this study, a number of observations can be highlighted. First, the process is notably different from the procedure unfolding for irregular migrant victims of human trafficking. Indeed, under the Dutch anti-trafficking frameworkwhich provides for both a 'reflection period' and the possibility for (temporary) residence status - victims are provided with various forms of assistance and support, including accommodation, medical and psychological assistance,

69 Interview with Police (Amsterdam), Feb. 2019.

$70 \quad$ Ibid. 
legal assistance, and they are permitted to work. ${ }^{71}$ These forms of assistance are key features that contribute to the promotion of greater reporting of crime among irregular migrants. ${ }^{72}$ In contrast, under the 'free in, free out' policy there is no formal arrangement to ensure victim protection services. As will be shown in the following section, this presents significant challenges and limitations in terms of access to basic services and victim protection.

Various important challenges and limitations were found with respect to the Dutch 'free in, free out' policy. This section focuses on three: (1) the fragile or 'thin' nature of the firewall between police and immigration authorities, reflecting a discretionary 'do not enforce' policy; (2) the lack of access to services and protection for victims; and (3) the inconsistency in practice and pervasive lack of trust at the local level that leads to unequal treatment.

\section{1}

\section{'Do Not Enforce': Assessing the Nature of Firewall Protection under the 'Free In, Free Out' Policy}

The purpose here is to delineate and define more precisely the nature of the 'firewall' protection' that the 'free in, free out' policy offers, and to identify its limitations. In the first place, we see that regular duty officers often contact immigration police when confronted with irregular migrants-often to obtain information or advice on how to proceed. Notably, the immigration police are often then the ones who inform regular duty officers whether or not the irregular migrant in question should be permitted to safely report a crime. At first glance, this process reflects a stark departure from a complete 'firewall' protection that provides for a 'don't ask', 'don't tell', and 'don't enforce' approach. ${ }^{73}$ In principle, such a firewall policy would explicitly prevent regular duty police officers from contacting immigration officials when responding to irregular migrants who are victims of crime. Furthermore, the practice of reporting victims to immigration police may undermine the notion of 'free in, free out'. In these cases, the 'safe reporting' process might begin with the irregular migrant entering the police station 'freely', but it ends with the immigration police not

\footnotetext{
$71 \quad$ NRM 2018, p. 96.

72 Van Londen, M. \& Hagen, L. (2013), Evaluatie van de pilot 'Categorale Opvang voor Slachtoffers van Mensenhandel'. Den Haag: woDc, available at https://www.wodc.nl/ onderzoeksdatabase/evaluatie-pilot-categorale-opvang-slachtoffers-mensenhandel .aspx.

73 Crépeau, F. \& Hastie, B., 2015, supra note 11.
} 
only learning about the incident, but also about the name, residence status, and presence at a particular locality of the individual in question. In other words, the irregular migrant reporting a crime invariably leaves behind a (digital) footprint with the immigration police that can be accessed in future confrontations. Potentially, this practice also raises the perceived risk of detection and arrest among irregular migrants, and may discourage victims from coming forward, regardless of whether or not the information provided to the immigration police is used.

In view of these processes, the policy, as it is currently implemented, appears to most closely reflect the 'don't enforce' component of a 'firewall' approach. Interestingly, the 'free in, free out' policy significantly differs from the better-known 'firewalls' established by sanctuary cities in the US because it is not the local police authorities refusing to enforce federal immigration law (as is the case in the US $){ }^{74}$ but rather immigration authorities not enforcing the immigration laws. In this respect, the nature of the 'firewall' between regular duty police and immigration authorities under the 'free in, free out' policy is decidedly fragile.

This raises the basic question: why does the 'free in, free out' policy not reflect a more robust 'don't ask' or 'don't tell' form of protection? This kind of 'thin' firewall protection may again be seen, in part, as a consequence of the 'thick' enforcement system that exists in the Netherlands. Indeed, stricter enforcement produces a greater need for 'firewall' protection, as irregular migrants are subject to much higher apprehension risks. However, it also demands a certain kind of 'firewall' protection that is necessary to meet particular public safety needs or victim protection obligations, while at the same time not undermining state enforcement interests. This in turn translates into the kind of 'don't enforce' firewall protection system in which immigration enforcement authorities maintain far-reaching apprehension mandates and a high degree of discretionary authority. However, as will be further elaborated upon below, this also contributes to significant inconsistency in practice, and reinforces a lack of trust between irregular migrants and the police.

\subsection{Limited Services and Protection for Victims}

The 'free in, free out' policy provides no formal access to additional support services or protection for victims. In principle, all victims of crime-including those with irregular status - should have access to a number of ordinary support services for victims, including access to Victim Support Netherlands [Slachtofferhulp Nederland] - a victim support agency that helps victims 
obtain access to counselling services, compensation for damages, and legal support-, the Sexual Assault Centre [Centrum Seksueel Geweld], as well as basic medical services. ${ }^{75}$ However, there remain challenges with respect to access to these services, particularly in relation to accommodation provision. For instance, while the Dutch B8/9 framework provides for a specific accommodation scheme for irregular migrant victims of trafficking, ${ }^{76}$ no such scheme is provided for irregular migrants who experience other forms of crime, including domestic or sexual violence. As an NGO stakeholder identified, the organisation Veilig Thuis-a national contact point for connecting domestic violence victims with essential services, including accommodation-does not extend access to accommodation for undocumented victims. It was indicated that support organisations are therefore often responsible for making informal or ad hoc arrangements to gain access to services for their undocumented clients, such as crisis shelters in situations of sexual or domestic violence. An NGO informant described an urgent situation in which a client who was victim of domestic abuse required accommodation:

There was nothing available, so eventually I called someone from the city and said, 'listen, this is the situation, can we figure something out?' So they contacted another official from a different municipality like, 'hey, do me a favour'. [...]. Eventually it was okay, and she received accommodation, great. [...] But it was completely dependent on the personal relationship that I had with the person from the city, who then also happened to have a personal relationship with someone from another city, who did them a favour. [...]. That's how it goes.

These accounts illustrate that, in the absence of formal arrangements for the provision of follow-up support and essential services to irregular migrant victims of crimes, the level of the support and protections is often dependent on

75 Also in accordance with the EU Victims' Directive; see Parliamentary Papers [Kamerstukken] I, 2014/2015, 34 236, nr. 3., Implementatie van richtlijn 2012/29/EU van het Europees parlement en de Raad van 25 oktober 2012 tot vaststelling van minimumnormen voor de rechten, de ondersteuning en de bescherming van slachtoffers van strafbare feiten, en ter vervanging van Kaderbesluit 2001/220/JBZ (PbEU 2012, L 315), p. 4. See also Hintjens, H.M., Siegmann, K.A. \& Staring, R. (2020), Seeking health below the radar: Undocumented People's access to healthcare in two Dutch cities, Social Science \& Medicine, 248, doi: 10.1016/j .socscimed.2020.112822.

76 CoMensha 2018; see also Categorale Opvang voor Slachtoffer van Mensenhandel (cosm) (n.d.), https://www.wegwijzermensenhandel.nl/organisatieprofielen/Categorale OpvangvoorSlachtoffersvanMensenhandelCOSM.aspx. 
the social capital of the victims, and the resourcefulness or goodwill of the persons they happen to approach for help.

\subsection{Inconsistency and Lack of Trust at the Local Level}

In relation to both initial reporting process and follow-up proceedings (including victim assistance and support), one of the central challenges that emerges in Dutch 'firewall' practices is the lack of trust and consistency in practice at the local level. All civil society actors interviewed viewed the policy as a positive and essential practice, and various NGO informants indicated that they had experienced some improvements in the area of 'safe reporting' policies, and had encountered positive examples of irregular migrants who were able to successfully and safely reports crimes. However, its potential impact is often held back by failures in practice and implementation. As one participant explained:

Sometimes it also goes really well, with a lot of attention and sensitivity for the victim. [...]. But so often it requires convincing [the police], chasing after them, repeating everything. So much of the responsibility is pushed to us, or to the victim, to inform them. And even then it is often from the position of 'we are doing you a favour', instead of, 'hey, this is a normal thing that we do, this is just our job, because we are the police'.

Other NGO informants likewise identified that the current policy demands a considerable degree of effort on the part of civil society organisations to guarantee that their clients will be able to safely report without the involvement of immigration authorities. One of the NGO informants indicated that, among an estimated 15 situations of 'safe reporting' involving their clients per year, approximately half of these cases were received with hostility or a negative response from the police. For instance, that the initial officer of contact was unfamiliar with the policy, was hesitant or unfriendly, or refused to guarantee safety. Additionally, it was identified that there is significantly less awareness of the policy among police outside the large cities. ${ }^{77}$ Generally speaking, localities where authorities have fewer interactions with irregular migrants were less likely to be aware of the policy.

In light of these inconsistencies, it is common practice among NGOs that, if a client indicates their desire to report a crime, the organisation will contact the police in advance to ensure that their client will not be arrested. They are often required to inform the police that there even exists a possibility to safely report. Describing this process, one of the NGO informants poignantly

77 Interviews with NGOs and Police (Amsterdam), Feb./March 2019. 
explained: "I would still never encourage my clients to go to the police station on their own. It's just not safe enough". This raises significant concerns as many irregular migrants in the Netherlands do not have access to support and assistance from NGOs and other civil society actors (particularly outside the larger cities), and may instead rely on informal support from family members, friends, or other personal contacts. ${ }^{78}$ These accounts therefore raise important questions regarding what happens when crime victims with irregular status lack the benefit of a well-informed NGO supporting them in the reporting process. It also raises significant concerns in terms of the effectiveness and legitimacy of the policy in providing meaningful safe access to police for all irregular migrant victims of crime.

In sum, despite its nation-wide implementation, the 'free in, free out' policy continues to be plagued by local-level inconsistencies. In general, the interviews indicate that there remains a lack of confidence and trust from civil society actors and their clients in the ability of these policies to ensure that irregular migrants can safely report crime, without risk of arrest or detention. As one NGO informant explained: if the policy is improperly implemented, it serves to cripple the message in a way that makes it impossible to convince people to make use of it. In light of these accounts, it must be emphasised that a lack of consistency in practice and implementation should not be regarded as a minor or secondary issue. Rather, establishing uniformity should be viewed as fundamental to robust and meaningful firewall protection. Failure to do so may threaten to undermine the effectiveness and legitimacy of the 'free in, free out' policy, and any 'firewall' protection for victims of crime in general.

Arguably, at the root of this inconsistency is the lack of a more robust 'firewall' between regular police and immigration police. Indeed, based on these accounts it may be questioned whether simply adhering to a 'do not enforce' approach should be regarded as firewall protection at all. However, the 'free in, free out' policy is clearly intended to provide some degree of separation between immigration enforcement and victim protection-but it comes with inherent limitations. In this respect, these accounts illustrate why a stricter, more explicit firewall at the 'do not ask' and 'do not tell' stage of the reporting process is so important; namely, that it can serve prevent precisely the kind of inconsistencies that currently plague the Dutch 'free in, free out' policy, and in turn establish a greater degree of trust with migrant communities.

78 Engbersen, G., Staring, R., Leun, J. van der, Boom, J. de, Heijden, P. van der, Cruijff, M. (20o1). Illegale vreemdelingen in Nederland. Omvang, overkomst, verblijf en uitzetting, Rotterdam: RISBO. 
This article seeks to help rekindle the discussion surrounding the need for 'firewall' protection for irregular migrant victims of crime in Europe. In particular, it focuses on the Dutch 'free in, free out' policy as a valuable case study, tracing its development from a local pilot project to national policy in 2015 as part of the official implementation of the EU Victims' Directive in the Netherlands. While the 'free in, free out' policy remains a unique and innovative example in Europe and is widely recognized as a European best practice in the area of victim protection for irregular migrants, prior to this study there has been little critical assessment of the nature and outcomes of the policy, and the significant gaps and challenges in practice and implementation. In this respect, the analysis presented in this study provides a number of insights:

First, immigration control in the Netherlands tends toward a 'thick enforcement' system defined by a number of unique practical and juridical features that are important to understanding the nature and challenges of 'firewall' protection. Since 2013, the Netherlands has had a National Police service, of which regular duty police officers and immigration police work in close collaboration with one another in areas of immigration control. Additionally, (1) the Netherlands maintains a sweeping digital infrastructure whereby information concerning an individual's residence status is accessible to an extensive range of national, regional, and local public agencies; (2) every person in the Netherlands is required to provide valid proof of identification to the police upon request; and (3) the police are authorised to stop persons in order to check their identity, nationality, and residence status if there exists a 'reasonable suspicion' of irregular residence. Arguably, such a strict enforcement system also produces a greater need for 'firewall' protection, as irregular migrants are subject to much higher apprehension risk, and are therefore more fearful or reluctant to go to the police. However, it also demands a certain kind of 'firewall' protection. The policy that ultimately developed in the Netherlands is therefore one that most closely reflects a 'do not enforce' system, and the nature of the 'firewall' between regular duty police and immigration authorities is decidedly fragile. This may be seen in large part as the result of an institutional contradiction between, on the one hand, a 'thick' immigration enforcement system that is characterised by a high degree of state interest and capacity to enforce immigration control and carry out deportations in line with 'return obligations' (under the Returns Directive), and on the other hand, a public safety-oriented agenda driven by both crime prevention demands and increasing victims' rights obligations (under the Victims' Directive). Indeed, the nature of the 'free in, free out' policy as a largely informal arrangement-not 
formally codified in national law-may be seen to reflect a pragmatic effort among Dutch policy-makers to balance these demands.

As a result, despite its nation-wide implementation, the 'free in, free out' policy continues to be plagued by local-level inconsistencies. In general, it was apparent that, although the policy was generally seen as a positive practice, there remains a lack of confidence and trust from civil society actors-and, most importantly, their clients - in the ability of these policies to really ensure the possibility to safely report crime. There also appears to exist a considerable degree of disparity in awareness among police, particularly between urban and rural localities. The inconsistency between urban and rural localities may be explained, in part, because larger Dutch cities have greater public safety demands with regard to protecting immigrant communities (and often higher frequency of contact with such communities), and therefore a reduced tendency for purely enforcement-driven practice towards irregular migrants. Ultimately, this lack of consistency and uniformity in implementation may threaten to undermine the legitimacy and effectiveness of the policy.

Despite the challenges and limitations that were identified, the 'free in, free out' policy was nevertheless recognised by all stakeholders interviewed, as well as in the broader literature among migrant and human rights observers, as essential for the protection of irregular migrant victims of crime; one that may potentially be exported to other European countries, and one that certainly demands more attention from policy-makers, social science researchers, and legal scholars. Looking forward, the need for firewall protection for irregular migrant victims of crime will be increasingly relevant. In recent months, the European Commission has announced that it is developing its new Victims' Strategy 2020-2025, in line with the EU Victims' Directive. ${ }^{79}$ At the very same time, the Commission is in the process of adopting a new (recast) Returns Directive, ${ }^{80}$ potentially reflecting a much stricter approach to the Union's return policy by, inter alia, expanding the grounds on which an irregular migrant may be administratively detained, reducing the possibility for voluntary

79 European Commission (2020, February 21), Statement by Vice-President Jourová and Commissioner Reynders ahead of the European Day for Victims of Crime, Brussels: European Commission, available at https://ec.europa.eu/commission/presscorner/detail/en/state ment_20_304; Milquet, J. (2019), Strengthening Victims' Rights: From Compensation to Reparation - For a new EU Victims' strategy 2020-2025, Brussels: European Commission, available at https://ec.europa.eu/info/sites/info/files/strengthening_victims_rights_-from_compensation_to_reparation_rev.pdf.

8o Proposal for a Directive of the European Parliament and of the Council on common standards and procedures in Member States for returning illegally staying third-country nationals (recast), a contribution from the European Commission to the Leaders' meeting in Salzburg on 19-20 September 2018, Сом/2018/634 final. 
departure, and strengthening the definition of 'risk of absconding', in an effort to increase the number of returns. ${ }^{81}$ In the case of irregular migrants, these two developments intersect in important ways. It is clear that, in order for irregular migrant victims to derive meaningful benefit from the rights and protections set out under the Victims' Directive, it is essential that they are able to report to the police without fear of being discriminated against on the basis of their residence status. However, as states ramp up their immigration enforcement and removal efforts, barriers to safe reporting become all the more significant. Furthermore, it is questionable how a combined reading of the Returns Directive with the rights established by the Victims' Directive allows for a generic non-enforcement of a return decision in the kinds of situation where the 'free in, free out' policy is applied. In this respect, the intersection between (increasingly strict) return obligations for Member States under the (recast) Returns Directive, and the obligation to provide victims with meaningful safe access to report to the police under the Victims Directive, raises important questions for European legal scholars.

It is in any case clear that, absent serious efforts to overcome the real and perceived risk of apprehension or deportation among irregular migrants, those who fall victim to crime will continue to face significant barriers in obtaining basic access to protection and justice. Firewall protection must therefore be recognized as a key tool for overcoming these barriers. The 'free in, free out' policy strikes a balance that manages to provide some basic degree of protection for irregular migrant victims of crime, even within the context of a 'thick' enforcement regime. In this respect, the policy may be recognized as a valuable first step in Europe, and one that offers a unique and innovative model that carries important lessons and insights for European national and local policymakers seeking to develop similar forms of firewall protection for irregular migrants who are victims of crime.

\section{Acknowledgements}

This article has been revised from a report initially prepared for the University of Oxford's Centre on Migration, Policy and Society (COMPAS) and the Global Exchange on Migration and Diversity as part of a research and

81 Eisele, K. (2019), The Proposed Return Directive (recast): Substitute Impact Assessment, Brussels: European Parliamentary Research Service; Peers, S. (2018, September 12), Lock 'em up: the proposal to amend the EU's Returns Directive, EU Law Analysis, available at http://eulawanalysis.blogspot.com/2018/og/lock-em-up-proposal-to-amend-eus.html. 
knowledge-exchange project exploring law, policy and practice surrounding the reporting of crime by irregular migrants in the US and four European countries (Belgium, Italy, Spain, and the Netherlands); for the original report, see Timmerman, R., Leerkes, A. \& Staring, R. (2019), Safe Reporting of Crime for Victims and Witnesses with Irregular Migration Status in the Netherlands, Centre for Migration, Policy and Society, University of Oxford. The authors also wish to thank the anonymous reviewer for the helpful comments, and Thomas Spijkerboer and Carolus Grütters for sharing their expertise with us regarding the legal status of the 'free in, free out' policy. 